\title{
Digital Wallets 'Turning a Corner' for Financial Inclusion: A study of Everyday PayTM Practices in India
}

\author{
Tanmay Joshi ${ }^{1}$, Sharmistha Swasti Gupta ${ }^{2}$ and Nimmi Rangaswamy ${ }^{3}$ \\ ${ }^{1}$ International Institute of Information Technology, Hyderabad, India \\ tanmay.joshi@research.iiit.ac.in \\ ${ }^{2}$ Indraprastha Institute of Information Technology, Delhi, India \\ sharmistha16193@iiitd.ac.in \\ ${ }^{3}$ International Institute of Information Technology, Hyderabad, India \\ nimmir@iith.ac.in
}

\begin{abstract}
Financial transactions are intimately bound with social interactions and woven into everyday economic lives. In this paper we focus on PayTM, a digital wallet, and a specific set of users of PayTM, street vendors in urban India. Through an ethnographic investigation we offer to unpack two questions: 1 . Can digital forms of money create financial inclusion by opening up access to the marginalized 2. Can digital platforms amplify socio-economic capacities of low literate users enhancing financial literacy? We argue that digital and financial literacy are an immersive component of digital wallet use acquiring 'everyday life' in specific socio-economic ecosystems. Our study captures daily practices of digital money staking a claim in advancing the understanding of financial inclusion as a lived process accumulating habits, practices and stakes to expand socio-economic capabilities.
\end{abstract}

Keywords: Financial Inclusion, Digital Wallet, PayTM, Ethnography, India,

\section{Introduction}

Bill Maurer refers to the use of financial instruments as 'appearing in accordance with a desire to alter financial status' - a powerful reference to the 'meanings' users infuse their economic transactions in everyday life [1]. The paper proposes to study and explain everyday practices and implications of the digital wallet, PayTM, in urban India as an instrument of financial inclusion. We attempt to probe two broad questions that set the context for the rest of the paper 1. Can digital forms of money represent the 'next stage' in the evolution of money to create financial inclusion; 2. Can digital platforms be viewed as optimising and amplifying user capacity to transact with money? We engage with the above questions to interrogate the following: First, is digital money in India expanding technology literacy? Second, does digital money support micro-entrepreneurship in the context of street business prevalent in India? By virtue of the above two questions we ask a third; is digital money an instrument of financial inclusion? We wish to add another layer of inquiry to deconstruct bottom up processes enabling financial inclusion through PayTM among marginalised users in urban India - does digital money promote easy and efficient access to financial transactions in the 'everyday'. We 
employ an immersive context study of PayTM in India among micro and small street vendors in two Indian metropolitan regions. PayTM embarked on its journey in the Indian mobile commerce platform by offering recharge and bill payment services in 2010 on boarding 25 million wallet users in the first two years of its introduction. With 150 million users on the platform, PayTM has become synonymous to e-wallet and added five million new users, 62.9 million transactions and registered over seven million transactions worth INR 1.2 billion every day in June 2018 [2]. These numbers exclude approximately a billion and 150 million Indians from the e-wallet platform. The challenges faced by PayTM and its acceptance from the banked and unbanked segments are both a broader issue of shifting gears from a traditional transactional system and a more immersive one of gaining technical and financial literacy. While PayTM is predominantly a part of the digital wallet universe, a recent study [3] situates digital payments 'within a larger undertaking of technology-driven modernity that drives these initiatives, rather than just efficiency or productivity gains...'. What does it take to cast PayTM as a modern technologically driven instrument of financial inclusion in India? We argue that digital and financial literacy are an immersive component of PayTM or digital wallet use and interrogate this premise in the context of micro-entrepreneurship and street vending in urban India.

Financial inclusion intermediates different actors in an economy: providing opportunities for the poor to improve the regularity of incomes and quality of life; for vendors and suppliers to provide steady low-cost savings; and for the state to channelize funds and reduce poverty [4].New practices in the domain of financial inclusion invite new powerful players and practices to intermediate the lives and fortunes of the poor. While MFIs, community-based programmes and cooperative institutions are the gold standards for financial inclusion, actors like payday lenders, large banks, technology firms, mobile network operators and credit card companies are now 'included' as agents of financial inclusion. The latter blurs the lines between different types of service providers and practices in the domain of financial inclusion to create an 'enabling' environment for new technologies' [5]. The Indian government, since 2014, has emerged as the organ of financial inclusion for the country, with its 'largest financial inclusion scheme in the world' [Pradhan Mantri Jan Dhan Yojana] for universal bank accounts, promotion of cashless payment cards and the strategic strike of 'demonetization' of high-denomination rupee notes in late 2016, aimed at driving the uptake of digital financial services [6]. This sets up a compelling context to situate PayTM as a private player arbitrating digital money uptake, technology literacy and an entrepreneurial emissary for the low resourced street merchants in India. A more pressing question is if digital payment systems acquire everyday life within the constraints of a specific socio-economic system? We attempt to identify processes promoting 'financial inclusion' and modes of acquiring 'literacies' in order to participate in the processes of 'financial inclusion'. In this paper, the context of street vending offers a backdrop to map the journey of PayTM as an instrument of financial inclusion and the challenges in acquiring digital literacies as part of business practice.

\section{Literature Review}

In this section, we offer an understanding of financial inclusion around digital wallets and payment platforms while situating digital money in the ongoing discussion on financial inclusion. A simple definition of financial exclusion is the inability to access necessary financial services in an appropriate form [7]. Financial institutions are seen as a 'coalition of depositors' [8] providing a diversity of services to low income and subsisting populations in 
developing countries who manage money primarily through informal networks lying out of the formal financial system. Financial inclusion is both pro-poor as well as pro-growth creating access to financial services and opportunities to use savings and credit to make productive investments [9-11]. Only 35\% of the adults in India have access to an account at a formal financial institution [12]. Major financial inclusion policies follow a supply side-centered approach providing access to basic banking services such as a 'no-frills' savings account [13]. However, when bank accounts remain largely under-used and informal money management persists, it is necessary to consider people's constraints and rationales that go beyond behavioural constraints [13]. A major critique of financial inclusion strategies is the inability to address financial arrangements in interconnected socio-cultural contexts including the household, the larger village or town, the banking systems and infrastructures of financial access [14]. A range of research studies suggests mobile money services as a subset of 'what will eventually be an extremely diverse ecosystem of mobile technology-based offerings, many of them outside the financial sector' [15-17]. New practices of financial inclusion bring powerful players into organized financial dealings with the poor and the underserved blurring different types of service providers and practices [18]. A report commissioned for Visa estimates that micro and small merchants in developing countries alone will pay around 35 billion USD annually in fees, if their transactions, amounting to more than 6.5 trillion USD, are digitized and brought into the formal financial system [19]. The broad emphasis on competition as a supposed driver of financial inclusion suggest private profit-seeking entities (which respond to competition) should take the lead [20].

The rapid penetration of mobile phones and the growing popularity of smartphones in the developing nations have created tremendous opportunities and severe challenges for conventional payment systems dominated by traditional banking and financial institutions [2124]. India is home to more than 145 million unbanked families, a potential segment for financial inclusion via mobile phones [25]. Mobile banking and digital wallet technologies are the new locus expanding financial capacities by reducing costs of transaction making payments electronically transferrable and a variety of small transactions cheaper, easier and faster for service providers and customers [26-29]. But how expansive and deep are these instruments and does sustaining and deepening mobile money services for financially excluded population require a far more socially multi-faceted approach? [30]. One explanation commonly put forward by financial inclusion advocates such as the G20 experts [31], is 'low levels of financial capability' form a significant barrier for many poor and low-income people to fully recognize formal financial sector offerings, and how they must behave to benefit from them. For example, Deb and Kubzansky [32] argue about the 'financial capability gap' - the lack of skills and knowledge to make informed financial choices impacting low-income earners adversely in understanding the implications of their choices and actions'. Bawden [33] and Eshet-Alkalai [34] caution about the inconsistency between those who conceive digital literacy as 'primarily concerned with technical skills and those who see it as focused on cognitive and socio-emotional aspects of working in a digital environment'[35]. From a sociocultural perspective literacy is then a matter of social practices [36] and is 'best understood as a shorthand for the social practices and conceptions of reading and writing' [37] and 'a set of socially organized practices which make use of a symbol system and a technology for producing and disseminating it', which in other words means "applying knowledge for specific purposes in specific contexts of use' [38].

PayTM as a digital wallet and agent of financial inclusion is claiming a phenomenal increase in adoption of digital payments in tier two and three cities of India constituting $50 \%$ of the 
total user base: a major factor being the multilingual app used by over $25 \%$ of users. The platform, over the past year, on-boarded $100 \%$ more female users and 300 thousand villages, 3 million merchants [39] accepting digital payments in small towns through cashless transactions through its smartphone app and QR code solution. The platform is powering the largest offline payments network with over 8 million offline merchant partners who accept payments via the PayTM QR [40]. While millennials continue to be the most active users, the platform surged with an annual run rate of 5 billion transactions and 50 billion USD GTV (Gross Transaction Value) [40]. PayTM claims to be the largest contributor towards all forms of digital payments including UPI, Wallet and Cards and, since January 2018, processed over 400 million digital transactions, a preferred alternative to net banking. It also saw a $500 \%$ growth [40] in money transfer transactions with offline stores accepting PayTM payments directly into their bank accounts. This new feature will accept payments from any bank account into their bank accounts at zero transaction charges [41]. Much of our paper engages with aspects of situation driven challenges to viewing PayTM, despite its apparent uptake, as socio-cultural phenomenon inhibiting small-scale businesses to optimize income generation. We introduce the notion of 'digital literacy' as 'contextually framed' and 'learnt' in the processes of street vending and mobile money transactions.

\subsection{Social Use of Money}

In this section we specifically draw attention to studies that highlight the intersections of digital money and their social contexts. Digital currencies and payment technologies not only offer new ways of interacting with money but also transform user's understanding of financial operations, how they occur, making sense of financial information and ways in which new forms of money or payment methods change social interactions [42]. Studies have drawn attention to the importance of ecosystems surrounding mobile payments and suggest targeted yet different solutions for the tech-savvy and the under resourced markets - where the former allowed more state-of-the-art solutions and the latter basic solutions aiding financial inclusion [43]. Conceptions of locality, community, identity, information exchange 'impact the use of digital and physical forms of money while forms of currency can make the invisible visible, exposing identities and values as much as business models and transaction details'[44]. The adoption of digital money is shot through with cultural and social factors that constitute its specific character; one such example are 'the Japanese conceptions of the aesthetic and moral virtue of smooth flow and avoidance of commotion' impinging on not only the design but also user adoption of digital money. Implications for design of mobile payment systems stress the need to 'produce open-ended platforms that can serve as the vehicle for multiple meanings and experiences without foreclosing such possibilities in the name of efficiency' [45]. Another study reports on a specific digitally mediated transaction system (transactions are mediated by a third phone transferring money from one account to another through a SMS notification request) affording 'opportunities for rich social interactions through which individuals are able to express themselves as members of their community and make lasting connections based on trust'. The authors elaborate on social meanings of money building rapport and, in particular, trust-based transactions inextricably linked with the community of transactions or users of digital money enabling 'reciprocation of common concerns' [46]. In this paper we offer a variety of ways in which the marginalised merchant population in urban India socially adapt and adopt PayTM adjusting and expanding their understanding of 'money' as de-materialised digital currency.

\section{Methodology}


The study builds on our findings from ethnographic observations and interviews conducted amongst street vendors in urban Indian markets to investigate PayTM as a mode of payment in their day-to-day dealings. Our aim was to urge respondents to elucidate their everyday business transactions to uncover the socio-economic factors behind the usage of PayTM. We carried out fieldwork in five markets in two regions of the country: the national capital region of Delhi (NCR), situated in North India and Greater Hyderabad, a metropolis and major technology hub in South India. The markets were Lajpat Nagar, a popular market with plenty of street-side vendors in South Delhi witnessing a footfall of about 100,000 people a day and 150,000 on weekends. Many of the shops sell women's clothes, shoes, apparels tending towards a female-dominated customer base. PayTM usage here is not widespread but definitely on the rise with cash being the predominant mode of payment. The second market in South Delhi, Nehru Place market, is a more male-centric shopping area in an office district. It is surrounded by offices, electronics goods shops, a few eateries, and frequented by office goers who work in the vicinity. This market witnessed a dramatic decline in the usage of PayTM with time post the demonetization initiative. Cash is the most convenient mode of payment, with vendors mandating digital transactions only for purchases worth more than INR 100 [1-2 USD]. The place in the NCR region, Murthal, a village in the Sonipat district of Haryana, situated around 31 miles from New Delhi is primarily an eatery district, locally called 'dhabas' serving staple North Indian cuisine. Travelers, traders, and tourists constitute the primary clientele. While the 'dhabas' accept payment in cash, debit or credit cards, as well as digital wallets like PayTM and Google Tez, the usage of PayTM wallet here, has been restricted to transactions valued not more than INR 1,000 [12 USD] - a sort of reverse mandate that was found in the Nehru Place market. We will dwell on the reasons for these mandates in our findings section. We studied two markets in Hyderabad city: DLF Street, located in the IT districts of Hyderabad hosting offices of giant tech companies opens at 4 PM and shuts shop at 2 AM. Many snack stalls cover a mile-long stretch of the roadside. The customers for these stalls are predominantly IT employees in 'the graveyard shift' and students from 2 universities nearby. PayTM is being used here not only as a wallet service for business but its partnership with Uber and the ability to extend use for the shopkeeper's personal expenses comes in handy. A key agent for adopting PayTM has been incentives like cashbacks and coupons. The second market, Indira Nagar, also located near the IT district of Hyderabad, is a big commercial street with a mix of shops, eateries, fitness centers and beauty salons. A row of small snack stalls dot the street, many of them appear and set shop on their cycles and carts in the evenings and briskly disburse street food vending business. Our observations and interviews were centered around the level of acceptance of PayTM wallet among the street vendors and their adoption of the wallet in reference to their everyday businesses. Broadly, our probes touched upon discussions around value, frequency, and context of transactions to figure out the level of comfort with PayTM usage for business, sometimes for personal use. PayTM wallet adoption history, financial interactions with other vendors and raw material suppliers were investigated to understand the overall embedding of PayTM in the street business ecosystems. Usability issues were also noted during interviews to engage with PayTM as a digital platform. We were alert during our research sessions about socio-cultural factors in the ecosystems of small vendors and shopkeepers influencing PayTM usage. A total of 25 semistructured interviews [21 male, 4 female] were conducted. The respondents fell in an age bracket of 22-55 years, including micro-business owners, street vendors, waiters, and Dhaba owners. Two researchers carried out the ethnography, took field notes, recorded and transcribed interviews and carried out a first order analysis of the findings. This was followed by a third researcher drawing relevant themes and weaving them together. 


\section{Findings: PayTM as Digital Transaction}

PayTM use is investigated as everyday money and it's sustenance as a digital channel for monetary transactions. We consolidate our findings from micro and small-scale street vendors in five commercial markets in the cities of Delhi and Hyderabad to understand the affirmative, uncertain and constraining economic, socio-cultural impetus for PayTM and digital money. Our ethnographic engagement accorded a more composite and heterogeneous adoption pattern and response to PayTM as a new digital channel of money exchange and transfer.

\subsection{PayTM - A walk Through}

We begin with a walk-through of PayTM usability features. New customers are required to register with a mobile operator and complete a 'Know Your Customer' verification using a national social security number [ called the Aaadhar in India] to perform digital wallet to digital wallet transactions. User can pay through scanning QR codes or entering their registered mobile phone number. People have the facility to add credit/debit cards, especially bank accounts to transfer money to PayTM wallets - and transfer money from PayTM wallets to bank accounts. PayTM can be used to transact the smallest amount of money but there are rules for transactions between the digital wallet and a bank- there are minimum and maximum capping for money transfers in a day and the total transacted money for a day. Merchants who sign up PayTM for business have more liberal capping amounts to promote adoption of digital money. We will address the ecosystem of PayTM as digital transaction in the following section and the meaning making of digital wallets as a financial instrument with immediate transacting capabilities like liquid cash.

\subsection{Making Meaning of PayTM as Financial Instrument : The Persistence of 'Cash'}

In this section, we look at the persistence of liquid money or cash, as a component of and driving valency to adopt PayTM as a financial instrument. Cash formed the crux of small business transactions in India and PayTM adoptions continued to use the 'notion of cash' as a measure of competency with the digital wallet. We unpack this 'notion of cash' in the following ethnographic vignettes. Nehru Place, a market in south Delhi, dominated by offices and male employees and well known for its 'electronic goods', payment through PayTM has dropped in the past year. Saurav works at a small stall in Nehru Place and sells tempered glasses and covers for mobile phones to 5-7 customers per day. Though his customers prefer cash an average day gets him around INR 700-800 [10 USD] through PayTM. The Lajpat Nagar market, a few miles away from Nehru Place but a wealthier market, the usage of PayTM is on the rise. But Shopkeeper Nitin, who deals with custom confiscated goods and clothes, owns a nice shop with glass doors, assessed his PayTM in terms of amount of 'cash' the digital wallet is bringing in ".. if I do not have PayTM on my phone I will lose 2-3 customers daily or INR 2000 [70 USD] worth of profit per day....” Amit, who runs a small business of readymade ladies' dresses, claimed to use PayTM even before demonetization due to its ease with small transactions - what would formerly have been a cash transaction, is now made easy due to PayTM. Sumit, a mobile vendor of snacks in the same market, says, "As long as people have PayTM on their phones, they won't feel handicapped with respect to money transactions in case they run out of cash. There is this sense of security that you have access to cash at any point in time." Shobha [female, early 40s], has been vending 'fashion' jewellery in Nehru Place. Her scope of business is small [she sells products between INR 20200 which is less than 1 to 4 USD] and isn't very ambitious about digital money. She is happy to go with the customer's preference. She sites cash crunch, the release of 2000 rupee notes 
and the withdrawal of 500 rupee notes pushing digital money transactions, "... Once the 500 rupee notes were back in circulation, 'cash' too became a dominant transactional mode." Apparently, demonetization pushed people to digitize their transactions - it was not organic to everyday behaviour with money. According to Sri Teja, a mobile street vendor selling Pani Puri, a popular savoury in the IT suburb of Hyderabad, "Even a penny can be transferred through the wallet. Digital money is small cash.” PayTM acquires new meanings consistent with and interpreted through existing notions of 'money' which in turn become drivers or constraints in the adoption of digital money.

\subsection{Is Digital Wallet a Bank too? Banking with PayTM}

New capacities for digital wallets allows it to function, as expressed by a young Ice- cream street vendor in Hyderabad, 'like a bank in a pocket'. How does banking come to the PayTM user? Does it bring financial inclusion or literacy? Our research does not offer neat answers to this question, evident in the following selection of our 'data for the field'. Madhav, who owns a small multi-purpose store, has an interesting story that goes beyond PayTM for his vending business. He has two bank accounts and has opted out of linking any of them to PayTM. PayTM was 'cash in and cash out' and Madhav did not explore the option of looking at PayTM money as bankable, despite the many affordances networking the wallet to banking. The manager of Gulshan Dhaba, in Murthal, a peri-urban area on the outskirts North of Delhi, had another issue. The cap by PayTM with regard to the volume of money transferable to his bank account was not optimal for the money that the wallet was making. He reverted to asking some of his customers for cash which could easily be deposited in a bank. During the early days of demonetization sales through card and wallets had increased multi-fold, making transferring of money from PayTM to the bank a thorny issue. Initially, a sum of 400 USD and later a sum of 1200 USD served as caps to move money from the wallet to the bank account. But this process depended on the account holder undergoing a detailed Know Your Customer $[\mathrm{KYC}]$ process which posed a set of new problems for people like Madhav; he had issues with filling out these forms in any language. PayTM stood in as 'temporary storage' of money; not an instrument that can pad a savings account in a bank. PayTM as this easy everyday wallet is rendered a complex transacting instrument when linked to banks and banking - the long documentation process such as the KYC demanded a certain kind of financial literacy.

\subsection{PayTM as a Situated and Shared Wallet}

PayTM appropriation by vendors in urban India followed a certain socio-cultural pattern borrowed from the everyday context of street vending. The digital wallet was not only part of a smartphone ecosystem but also part of a situated business ecosystem of micro-businesses optimized for small margins of profit. PayTM was a shared digital storage for cash; friendly neighbourhood-businessmen could operate PayTM jointly; they could use PayTM as a 'record keeper' for their business transactions; substitute PayTM money for lending and borrowing; enrol themselves as merchants on the platform. All of the above were first-time occurrences in the life of these 'businessmen'.

The DLF food street is abuzz in the wee hours of the morning, catering to IT workers on a late work shift in Hyderabad. Most of the street vendors had a longer history with PayTM use than those in the Delhi street markets. Sohail, the owner of Hi-fi Tiffin Centre selling Indian fast food, has seen the transition of PayTM in the last three years, 'from a glitch-ridden the platform to a smooth operating one'. He said, "My customers came with a request to pay through digital wallets and I realized the potential they had for business." Amit has three young men working under him, in a busy market street of Lajpat Nagar, New Delhi, who look after four different 
stalls selling dresses, humbly priced at 5-6 USD a piece. To Amit PayTM is a boon for street vendors - it 'functions as a log book' and aided managing co-workers without undue concerns about 'petty theft' in day to day business. A group of 4 vendors with individual stalls selling jewellery at throwaway prices share their business profits. One of them a young man named Rajat, currently performs only micro-transactions through his PayTM account but seemed enthusiastic about the entire concept of mobile wallets. Rajat shares this account with the four vendors around him. His product and price range result in small transactions, several through the ease of PayTM, and the proximity of co-vendors who he can trust has resulted in an organizational arrangement that optimizes their small business turnover without compromising on the benefits a digital wallet brings with it. "We pay each other cash to settle our account based on the PayTM records. That is one good thing with PayTM. There is a record of transactions."

Anand [male, 59] a small vendor in the Nehru Place market, selling files and folders along with fidget spinners was sharing his 'friend's' PayTM account. Anand insisted on his customers buying over 100 INR [ $<2$ US\$] worth of products in order to transact with PayTM. One of the authors had to buy a products worth around 100 INR to be able to pay using her PayTM wallet. In Lajpat Nagar, a lot of street vendors function in groups of three or four and share a PayTM account. Jatin owns an open stall in Nehru Place, that sells men's clothes using a couple of helpers. Jatin has two PayTM accounts and a self-confessed PayTM 'fan'; "I want notes to be banned and everyone should be made to switch to cashless transactions. It would also affect my sales because not everyone roams around with cash. A lot of people generally carry cards with them however, all places including my own stall, do not accept cards." He claims that there's been a huge increase in sales with around Rs. 2000 [25 USD] as PayTM money each day and around INR 7000-8000 [950 USD] a week. Sumit has an independent business selling Indian snacks he carries around on a bicycle in and around street markets in Delhi. On an average, he serves 250-300 customers in a day with a 10\% use of PayTM per day. Sumit is very PayTM proactive and has a merchant barcode for PayTM linked to his bank account. If his customers scan the barcode and make the payment, the money directly goes to his bank account. If they use his contact number to make the payment, it goes to his PayTM account. Sumit uses PayTM for micro-transactions like TV recharge, mobile phone recharge, small transactions for the household; "The system of mobile wallets is really great and useful. As long as people have PayTM on their phones, they won't feel handicapped, be it in the marketplace, bus tickets, local train tickets, PayTM can be used anywhere. There is a sense of security that you have access to money all the time.” Move 50 miles outside of a big city you find a different approach to digital platforms. Murthal, a location on the outskirts of South Delhi, is strategic for small eateries to serve people passing by to stop for meals. Sukhbir, 28, a waiter in the Tavva Rasoi Dhaba, Murthal, Haryana, said, "Everyone has a PayTM account here but how it's being used is known only by vendors like us.” To people like Sukhbir, PayTM like services seem to be an additional option to pay but does not affect sales per se. Interestingly the nature of context affects digital money exchanges; Sukhbir continued, "Our customer base either pay in large amounts (being in groups) or are payments from the lower-economic class (who do not even own a smartphone). I have had a PayTM account as well but there is little use for it here. Since I don't get money into it I don't take out money from it.” Dev, in his early twenties, works in Mannat Dhaba, a local eatery in Murthal on the outskirts of Delhi. He claims PayTM to be an alternate yet weaker platform with around 5\% of their daily number of transactions going through PayTM. Truck drivers who pass through or people from nearby are not typical PayTM users and usually go for cash (many do not have a Smartphone) whereas traders and people on an excursion opted for other payment techniques like PayTM and cards. Jagad, who sells 'paan', a digestive and mouth 
freshener, sits in a small kiosk outside the very popular Amrik Dhaba had a whopping 30-40\% of the payments through PayTM. His product, the Paan, is worth INR 20 to 25 [30 cents] per piece and suited the microtransaction quality of the PayTM wallet.

\section{A Discussion about PayTM and Acquired Financial Literacy}

In this section, we attempt to discuss and locate PayTM, specifically, and digital wallets, broadly, as bearers of financial inclusion in developing countries like India. Some of the themes we will touch upon are challenges to digitally executing tasks on PayTM, which rests on two major challenges - one, arising from everyday business dealings and second, from the broader socio-cultural response to capacity building on digital devices and platforms. While many of our participants in the study find scratch cards, cashbacks and coupons easy to utilize, they admitted to finding basic features of money transfers and banking via PayTM tough to execute. People like Sunil, a footpath vendor, who are otherwise savvy with the phone and aware of PayTM as part of the phone app ecosystem, mention literacy issues with operating code or coupons in the use of PayTM. Aman who owns an open stall in Nehru place selling mobile phone covers and managing three people working under him, could not adjust to the technical aspects of PayTM and decided to discontinue its services despite looking at a loss of around INR 3000-4000 per day. By 'technical' he mentioned 'whenever he would log out and try to sign in again', the app 'always flashed wrong password'. He had tried to contact customer care but had never been able to connect to them. He had also faced hassles while getting his KYC done. Aman mentions 'PayTM is only for micro-transactions' because he has never been able to trust PayTM as a system for banking. The virtual and digital aspects of PayTM were disconcerting - He said, "Companies like Airtel have service centres where you can go in order to raise any concern. But that isn't the case with PayTM.” Despite mobile wallets being 'huge time savers', issues in 'operating PayTM' were insurmountable for Aman. Sometimes, people like Sunil, the footpath vendor, make 'entry errors' of bank accounts 'when accidentally $4 \mathrm{k}$ was transferred to a client account during a bank transfer'. He was also worried that 'Losing my phone was like losing my actual wallet and exposing my bank accounts!” Interestingly, the more business-rich shop for 'confiscated goods' in the South Delhi market, separate their PayTM for business and personal use. PayTM and digital money was more to maintain and log their everyday business accounts and using cash in their personal transactions. With more of ethnographic persistence we understood that a lot of 'grey', unaccounted money, was used up as cash transactions in everyday use. An evolved literacy around digital wallets actually helped separating different forms of money and business dealings.

Sumit, the bicycle vendor of pastries, is 'in awe' with PayTM. For Sumit, micro-transactions and PayTM seem to share a symbiotic relation," "Small transactions can push towards and pull away from PayTM - it's so small that it's easy to cash out and at the same time PayTM is so easy when a small change is not available". Sumit goes on to say, "In my personal life, I use PayTM for TV recharge, mobile phone recharge, small transactions in the market like when buying milk etc. I have a merchant barcode for PayTM and its linked to my bank account.” If his customers scan the barcode and pay, the money directly goes to his bank account and if they use his contact number it goes to his PayTM account. "I trust PayTM more than my clients. As long as people have PayTM on their phones, they won't feel handicapped with respect to money transactions in case they run out of cash in the marketplace, for bus tickets, local train tickets. PayTM can be used anywhere, it provides you with this sense of security that you have access to money at any point in time." Sumit's acquired 'literacy' and persistence with PayTM in his everyday helped evaluate his experience with the wallet's 
social-technical eco system.

Several street entrepreneurs in our study did not concur with Sumit's enthusiasm. Many of them share PayTM accounts and the cap for money transactions did not bother them [they were doing small transactions] but re-distributing the money among themselves needed some 'off-digital' tactics. The vendors manually attempted to calculate 'who owed what to whom' and wished there were 'easier ways to unlock the money from PayTM'. Like Manish, owner of an ice-cream parlour near the Hyderabad's IT park, small vendors 'gave up' persisting with PayTM or the 'notion' of allowing digital wallet or money to enter their everyday business: "I did not go beyond the first month with PayTM after facing a technical glitch that impacted my payments! I still don't understand what went wrong! Even after PayTM removed transactional and transfer charges which ate into our profits, I believe PayTM is here to "pull wool over our eyes' as an easy, profitable and smooth option to run a small business.” Manish actually believed that digital money cut into his honest business earnings. Saurav, the owner of a footpath stall, uses PayTM for many reasons but has no bank account ; he was both eager and suspicious to use digital wallets and vest trust in their capacity to store and secure his money. For instance, it took a while for Saurav to understand ' mandated caps for the value of transactions per day on PayTM'. But the street vendor continue to persist with PayTM. Is Saurav's persistence with PayTM a result of acquired literacy through trial and error? Or is it demand for the wallet to easily execute micro-transactions pushing its adoption and thereby the literacies to use the wallet optimally? Is Saurav the emerging user of wallets like PayTM which is integrating the financially marginalised and underserved sections in the context of developing countries like India?

\section{Conclusion}

By way of conclusion, we suggest that the process of 'inclusion' is as much a bottom- up process even if engineered top down via national and state-driven economic policy. We explained PayTM use in the context of gaining digital literacy and their relationship to the street vending businesses in street markets in two Indian metropolises and their surrounding suburbs and peri-urban locations. A significant learning has been the reciprocal influence of business contexts [the type of business, range, and movement of products, nature of clientele, location] on the adoption practices of digital wallets. Social and business contexts operate as frameworks in the use of PayTM thereby affecting financial and digital literacy abilities. Digital-financial inclusion is as much a product of local actors and social systems as it is an achievement of the more formal economic and political enablers. Our paper outlined financial literacy, the bedrock of financial inclusion, an acquired habit borne from everyday practice and assemblage of experiences impacting consequences for the underserved and marginalized populations. We also made a compelling contextual inquiry of PayTM as stakeholder arbitrating acess to digital money uptake, technology literacy and entrepreneurial ability for the low resourced street merchants in India.

\section{References}

1. Maurer, B. How Would You Like to Pay?: How Technology Is Changing the Future of Money. Duke University Press, Durham, North Carolina (2015)

2. Laha, R. The battle of wallets: BHIM app Vs PayTM, Mobikwik, Freecharge. Hindustan Times (Jan 03, 2017). Retrieved from https://www.hindustantimes.com/business-news/the-battle-of- 
wallets-bhim-app-vs-paytm-mobikwik-freecharge/story- QM6h0lf3rTSv7bNn0klfiN.html

3. Pal, J., Chandra, P., Kameswaran, V., Parameshwar, A., Joshi, S., Johri, A. Digital Payment and Its

Discontents: Street Shops and the Indian Government's Push for Cashless Transactions. In Proceedings of the 2018 CHI Conference on Human Factors in Computing Systems (CHI '18). ACM, New York, NY, USA, Paper 229, 13 pages (2018).

4. Subbarao, D. Financial literacy and financial inclusion are integral to each other, speeches at the India-OECD-World Bank Regional Conference on "Financial education”, New Delhi (March 04, 2013). Retrieved from https://www.bis.org/review/r130305j.pdf

5. Maya Declaration: Commitments You Can Bank On. Alliance for Financial Inclusion (AFI) (2015). Retrieved from www.afi-global.org/sites/default/files/publications/maya_factsheet_2015_final.pdf

6. Chandrasekhar, C.P., Ghosh, J. The Financialization of Finance? Demonetization and the Dubious Push to Cashlessness in India. Development and Change 49(2), 420-436 (2018).

7. Carbó, S., Gardner, E., Molyneux, P. Financial Exclusion. Springer (2005)

8. Diamond, D. W., Dybvig, P. H. Bank Runs, Deposit Insurance, and Liquidity. The Journal of Political Economy 91(3), 401-419 (June 1983).

9. Chandran, B. P. S., Manju, T. K. Financial Inclusion Strategies For Inclusive Growth In India. Munich Personal RePEc Archive (MPRA) Paper, No. 33569 (2010). Retrieved from https://mpra.ub.uni-muenchen.de/33569/

10. Beck, T., Demirgüç-Kunt, A., Honohan, P. Access to Financial Services: Measurement, Impact, and Policies.The World Bank Research Observer 24(1), 119-145 (2009).

11. Sarma, M., Pais, J. Financial Inclusion and Development: A Cross Country Analysis. Indian Council for Research on International Economic Relations (ICRIER) (2008). Retrieved from http://icrier.org/pdf/Mandira\%20Sarma-Paper.pdf

12. Demirguc-Kunt, A., Klapper, L. Measuring Financial Inclusion: The Global Findex Database. Policy Research Working Paper No. 6025. World Bank, Washington, DC (2012). Retrieved from http://hdl.handle.net/10986/6042

13. Goedecke, J., Guerin, I., D’Espallier, B., Venkatasubramanian, G. Why do financial inclusion policies fail in mobilizing savings from the poor? Lessons from rural south India. Development Policy Review (2015). DOI: https://doi.org/10.1111/dpr.12272

14. RBI Speech https://rbidocs.rbi.org.in/rdocs/Speeches/PDFs/MFI101213FS.pdf

15. Villasenor, J. Smartphones for the Unbanked: How Mobile Money Will Drive Digital Inclusion in Developing Countries. Issues in Technology Innovation, Number 25 (2013). Retrieved from https:// www.brookings.edu/wp-content/uploads/2016/06/BrookingsMobileMoneyRevised-92313.pdf

16. Manikandan, S., Jayakodi, J. M. An empirical study on consumer adoption of mobile wallet with special reference to Chennai city. International Journal of Research - Granthalaya 5(5), 107-115 (2017).

17. Gabor, D., Brooks, S. The Digital Revolution in Financial Inclusion: International development in the fintech era. New Political Economy 22(4), 423-436 (2017).

18. Mader, P. Contesting Financial Inclusion. Development and Change 49(2), 461-483 (2018).

19. Carlberg, T., Lien, Y., Gomez, M. P., Nayar, A., Dougherty, J. Small Merchants, Big Opportunity: The Forgotten Path to Financial Inclusion. Dalberg Global Development Advisors and Global Development Incubator (2016). Retrieved from www.dalberg.com/system/files/2017-07/Smallmerchants-big-opportunity.pdf

20. Ledgerwood, J. The New Microfinance Handbook: A Financial Market System Perspective. World Bank, Washington, DC (2013). Retrieved from http://hdl.handle.net/10986/12272

21. Duncombe, R., Boateng, R. Mobile Phones and Financial Services in Developing Countries: a review of concepts, methods, issues, evidence and future research directions. Third World Quarterly 30(7), 1237-1258 (2009).

22. Leavitt, N. Are mobile payments ready to cash in yet?. Computer vol. 9, 15-18 (2012).

23. Dennehy, D., Sammon, D. Trends in mobile payments research: A literature review. Journal of Innovation Management 3(1), 49-61 (2015). Retrieved from https://pdfs.semanticscholar.org/e919/c9290b0bdc5ad3fdc8727425b493da164527.pdf

24. Wong, C. H., Lee, H. S., Lim, Y. H., Chai, B. B. H., Tan, G. W. H. Predicting the consumers' intention to adopt mobile shopping: an emerging market perspective. International Journal of 
Network and Mobile Technologies 3(4), 24-39 (2012). Retrieved from https://www.researchgate.net/publication/279298682_Predicting_the_Consumers'_Intentio n_to_Adopt_Mobile_Shopping_An_Emerging_Market_Perspective

25. Singh, A. "The future of mobile wallets in India". The Hindu: Business Line (March 10, 2016). Retrieved from https:/www.thehindubusinessline.com/catalyst/the-future-of- mobile-wallets-inindia/article8332085.ece

26. Gupta, A., Prahalad, C. K. Towards financial inclusion in India. SAMVAD International Journal of Management, SIBM Pune, pp. 66-70 (2011).

27. Thorat, U. Financial inclusion and information technology. Speech published in RBI bulletin (October 2008).

28. Rajan, R. G. A hundred small steps- report of the committee on financial sector reforms. Planning Commission, Government of India, pp. 64-87 (2008). Retrieved from http://planningcommission.nic.in/reports/genrep/rep_fr/cfsr_all.pdf

29. Ismail, T., Masinge, K. Mobile banking: innovation for the poor. African journal of science,

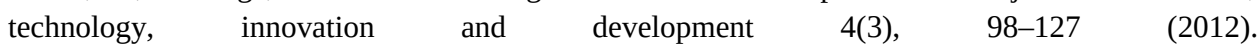
https://hdl.handle.net/10520/EJC132191

30. Zmijewska, A. and Lawrence, E. Reshaping the Framework for Analysing Success of Mobile Payment Solutions. Paper presented at the IADIS International Conference on E- Commerce, Porto, Portugal (2005). Retrieved from http://hdl.handle.net/10453/7318

31. "Innovative Financial Inclusion: Principles and Report on Innovative Financial Inclusion from the Access through Innovation Sub-Group of the G20 Financial Inclusion Experts Group”. Microfinance Gateway. Washington, DC: Consultative Group to Assist the Poor (2010). www.microfinancegateway.org/sites/default/files/mfg-en-paper-innovative- financial-inclusionmay-2010.pdf

32. Deb, A., Kubzansky, M. Bridging the Gap: The Business Case for Financial Capability. Citi Foundation (2012).https://www.citigroup.com/citi/foundation/pdf/bridging_the_gap.pdf

33. Bawden, D. Information and digital literacies: a review of concepts. Journal of Documentation 57(2), 218-259 (2001). DOI: 10.1108/EUM0000000007083

34. Eshet-Alkalai, Y. Digital Literacy: A Conceptual Framework for Survival Skills in the Digital Era. Journal of Educational Multimedia and Hypermedia 13(1), 93-106 (2004). Retrieved from https://wwfw.learntechlib.org/primary/p/4793/

35. Lanham, R. Digital Literacy. Scientific American 273(3), 160-161 (1995).

36. Gee, J., Hull, G., Lankshear, C. The new work order: behind the language of the new capitalism. 1st. edn. Westview Press (1996).

37. Lankshear, C., Knobel, M. Digital Literacies: Concepts, Policies and Practices. Peter Lang Publishing,NewYork,(2008).

38. Scribner, S., Cole, M. The Psychology of Literacy. Harvard University Press, US (1981).

39. PayTM's more welcome in rural, semi-urban areas. The Economic Times (June 2018). Retrieved from https://economictimes.indiatimes.com/small- biz/startups/newsbuzz/paytms-more-welcomein-rural-semi-urban- areas/articleshow/64535894.cms

40. “Tier II and tier III Cities are leading the wave of digital payments adoption”. PayTM blog (July 2018). Retrieved from https://blog.paytm.com/tier-ii-and-tier-iii-cities-are-leading- the-wave-ofdigital-payments-adoption-463a9c465ee

41. Cashless revolution! PayTM launches this new feature - Know what it is and how it works. Financial Express (June 2018). https://www.financialexpress.com/industry/technology/cashlessrevolution-paytm-launches-this-new-feature-know-what-it-is-and-how-it-works/1193424/

42. Mark Perry. 2017. Designing Interactions with Digital Money. Interactions. Vol. 24. No. 6. (October 2017). New York. ACM. Pp. 34-37.

43. Deepti Kumar, David Martin, and Jacki O’Neill. 2011. The times they are a-changin’: Mobile payments in India. In CHI'11: Proceedings of the SIGCHI Conference on Human Factors in Computing Systems. New York. ACM. Pp. 1413-1422.

44. Jennifer Ferreira and Mark Perry. 2014. Building an alternative social currency: Dematerialising and rematerializing digital money across media. In Proceedings of HCI Korea. Seoul. Pp. 122-131.

45. Scott Mainwaring, Wendy March, and Bill Maurer. 2008. From meiwaku to tokushita!: Lessons for 
digital money design from Japan. In CHI'08: Proceedings of the SIGCHI Conference on Human Factors in Computing Systems. New York. ACM. Pp. 21-24.

46. Jennifer Ferreira, Mark Perry, and Sriram Subramanian. 2015. Spending time with money: From shared values to social connectivity. In CSCW'15: Proceedings of the 18th ACM Conference on Computer Supported Cooperative Work \& Social Computing. New York. ACM. Pp. 1222-1234. 